\title{
Trends in taxonomy of Triatomini (Hemiptera, Reduviidae, Triatominae): reproductive compatibility reinforces the synonymization of Meccus Stål, 1859 with Triatoma Laporte, 1832
}

\author{
Natália Regina Cesaretto ${ }^{1 \dagger}$, Jader de Oliveira ${ }^{2,3+}$, Amanda Ravazi ${ }^{1}$, Fernanda Fernandez Madeira ${ }^{4}$, \\ Yago Visinho dos Reis ${ }^{1}$, Ana Beatriz Bortolozo de Oliveira ${ }^{4}$, Roberto Dezan Vicente ${ }^{1}$, Daniel Cesaretto Cristal ${ }^{3}$, \\ Cleber Galvão ${ }^{5^{*}}$, Maria Tercília Vilela de Azeredo-Oliveira ${ }^{4}$, João Aristeu da Rosa ${ }^{3}$ and \\ Kaio Cesar Chaboli Alevi ${ }^{1,3}$
}

\begin{abstract}
Background: Meccus' taxonomy has been quite complex since the first species of this genus was described by Burmeister in 1835 as Conorhinus phyllosoma. In 1859 the species was transferred to the genus Meccus and in 1930 to Triatoma. However, in the twentieth century, the Meccus genus was revalidated (alteration corroborated by molecular studies) and, in the twenty-first century, through a comprehensive study including more sophisticated phylogenetic reconstruction methods, Meccus was again synonymous with Triatoma. Events of natural hybridization with production of fertile offspring have already been reported among sympatric species of the T. phyllosoma subcomplex, and experimental crosses demonstrated reproductive viability among practically all species of the T. phyllosoma subcomplex that were considered as belonging to the genus Meccus, as well as between these species and species of Triatoma. Based on the above, we carried out experimental crosses between T. longipennis (considered M. Iongipennis in some literature) and T. mopan (always considered as belonging to Triatoma) to evaluate the reproductive compatibility between species of the T. phyllosoma complex. In addition, we have grouped our results with information from the literature regarding crosses between species that were grouped in the genus Meccus with Triatoma, in order to discuss the importance of experimental crosses to confirm the generic reorganization of species.

Results: The crosses between T. mopan female and T. Iongipennis male resulted in viable offspring. The hatching of hybrids, even if only in one direction and/or at low frequency, demonstrates reproductive compatibility and homeology between the genomes of the parents.
\end{abstract}

\footnotetext{
*Correspondence: clebergalvao@gmail.com

${ }^{\dagger}$ Natália Regina Cesaretto and Jader de Oliveira contributed equally as first authors

${ }^{5}$ Laboratório Nacional e Internacional de Referência em Taxonomia de Triatomíneos, Instituto Oswaldo Cruz (FIOCRUZ), Av. Brasil 4365, Pavilhão Rocha Lima, sala 505, Rio de Janeiro, RJ 21040-360, Brazil

Full list of author information is available at the end of the article
}

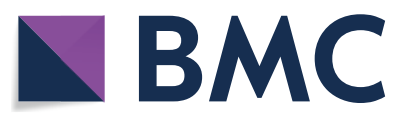

(c) The Author(s) 2021. This article is licensed under a Creative Commons Attribution 4.0 International License, which permits use, sharing, adaptation, distribution and reproduction in any medium or format, as long as you give appropriate credit to the original author(s) and the source, provide a link to the Creative Commons licence, and indicate if changes were made. The images or other third party material in this article are included in the article's Creative Commons licence, unless indicated otherwise in a credit line to the material. If material is not included in the article's Creative Commons licence and your intended use is not permitted by statutory regulation or exceeds the permitted use, you will need to obtain permission directly from the copyright holder. To view a copy of this licence, visit http://creativeco mmons.org/licenses/by/4.0/. The Creative Commons Public Domain Dedication waiver (http://creativecommons.org/publicdomain/ zero/1.0/) applies to the data made available in this article, unless otherwise stated in a credit line to the data. 
Conclusion: Considering that intergeneric crosses usually do not result in viable offspring in Triatominae, the reproductive compatibility observed between the T. phyllosoma subcomplex species considered in the Meccus genus with species of the Triatoma genus shows that there is "intergeneric" genomic compatibility, which corroborates the generic reorganization of Meccus in Triatoma.

Keywords: Chagas disease vector, Triatomines, T. longipennis, T. mopan, Experimental crosses

\section{Background}

Triatomines are hematophagous insects of great importance for public health, since they are considered the main form of transmission of the protozoan Trypanosoma cruzi (Chagas, 1909) (Kinetoplastida, Trypanosomatidae), the etiological agent of Chagas disease [1]. Currently, there are 8 million infected people worldwide and around 25 million living in an area at risk of infection [1], the control of vector populations being the main measure for the reduction of new chagasic patients [1].

Triatomines are part of the Hemiptera order, Heteroptera suborder, Reduviidae family and Triatominae subfamily [2]. There are 156 species in this subfamily, distributed in 18 genera and five tribes [3-6]. The Triatomini tribe is composed of nine genera, namely, Dipetalogaster Usinger, 1939, Eratyrus Stål, 1859, Hermanlentia Jurberg \& Galvão, 1997, Linshcosteus Distant, 1904, Mepraia Mazza, Gajardo \& Jörg, 1940, Nesotriatoma Usinger, 1944, Panstrongylus Berg, 1879, Paratriatoma Barber, 1938, and Triatoma Laporte, 1832 [3, 4]. However, during the taxonomic history within this tribe, several genera have already been considered valid: Eutriatoma Pinto, 1926, Conorhinus Laporte, 1833, Callotriatoma Usinger, 1939, Cenaeus Pinto, 1925, Neotriatoma Pinto, 1931, Lamus Stål, 1859, Mestor Kirkaldy, 1904, Triatomaptera Neiva \& Lent, 1940, and Meccus Stål, 1859 [7, 8]. Eutriatoma, Conorhinus, Neotriatoma and Meccus were the genera synonymous with Triatoma $[7,8]$.

Meccus' taxonomy has been quite complex, since the first species of this genus was described by Burmeister [9] as Conorhinus phyllosoma Burmeister, 1835; in 1859 the species was transferred to the genus Meccus [10] and in 1930 to Triatoma [11]. However, in the twentieth century, Carcavallo et al. [12] proposed the revalidation of the Meccus genus based on morphological data (alteration corroborated by Hypsa et al. [13] through molecular studies). Finally, in the twenty-first century, Justi et al. [8], through a comprehensive study including more sophisticated phylogenetic reconstruction methods, again synonymized Meccus with Triatoma.

The six species initially considered as Meccus [T. bassolsae Aguilar, Torres, Jiménez, Jurberg, Galvão \& Carcavallo, 1999, T. longipennis Usinger, 1939, T. mazzottii Usinger, 1941, T. pallidipennis Stål, 1872, T. phyllosomus (Burmeister, 1835), and T. picturatus Usinger,
1939], together with T. bolivari Carcavallo, Martínez \& Pelaez, 1987, T. mexicana (Herrich-Schaeffer, 1848) and T. ryckmani Zeledón \& Ponce, 1972, form the T. phyllosoma subcomplex [3]. This subcomplex, together with the $T$. dimidiata subcomplex [ $T$. dimidiata (Latreille, 1811), T. hegneri Mazzotti, 1940, T. huehuetenanguensis Lima-Cordón et al., 2019, T. mopan Dorn et al., 2018, T. brailovskyi Martínez, Carcavallo \& Pelaez, 1984, and T. gomeznunezi Martínez, Carcavallo \& Jurberg, 1994], form the T. phyllosoma complex [3, 14, 15].

Events of natural hybridization with production of fertile offspring have already been reported among sympatric species of the T. phyllosoma subcomplex [16]. Experimental crosses demonstrated reproductive viability among practically all species of the T. phyllosoma subcomplex that were considered as belonging to genus Meccus in some literature $[17,18]$. In addition, experimental crosses between these species and species of Triatoma from the T. phyllosoma subcomplex (T. mexicana) and the T. lecticularia complex [T. recurva (Stål, 1868)] also resulted in the production of hybrids $[19,20]$.

The study of reproductive barriers by experimental crossings was used in taxonomy (with emphasis on description, revalidation, and synonymization of species $[5,21,22]$ ) and systematics (with emphasis on the evolutionary relationship between species [23]) of Triatominae. Based on the above, we carried out experimental crosses between Triatoma species of the $T$. phyllosoma (T. longipennis) and T. dimidiata (T. mopan) subcomplexes, to evaluate the reproductive compatibility between species of the T. phyllosoma complex. In addition, we have grouped our results with information from the literature regarding crosses between species that were initially grouped in the genus Meccus with Triatoma, in order to discuss the importance of experimental crosses to confirm the generic reorganization of species.

\section{Methods}

Reciprocal experimental crosses were conducted between T. longipennis and T. mopan. These two species were chosen because both belong to the T. phyllosoma complex $[3,14,15]$, and T. mopan has never been considered as belonging to Meccus, unlike T. longipennis. The insects used in the experiment came from colonies kept in the Triatominae insectary of the School 
of Pharmaceutical Sciences, São Paulo State University (UNESP), Araraquara, São Paulo, Brazil. The experimental crosses were conducted in the Triatominae insectary, according to the experiments of Correia et al. [24] and Mendonça et al. [25]: the insects were sexed as fifth instar nymphs, and males and females were kept separately until they reached the adult stage to guarantee the virginity of the insects used in the crosses. For the experimental crosses, three couples from each set were placed in plastic jars (diameter $5 \mathrm{~cm} \times$ height $10 \mathrm{~cm}$ ) and kept at room temperature.

\section{Results and discussion}

As observed for the crosses between T. recurva and $T$. phyllosoma (as M. phyllosomus) [20] and between T. mexicana and T. longipennis [19], only the direction between T. mopan female and T. longipennis male resulted in viable offspring (Table 1). The hatching of hybrids, even if only in one direction and/or at low frequency (Table 1), demonstrates reproductive compatibility and homeology between the genomes of the parents.

Intergeneric crosses usually do not result in viable offspring in Triatominae (possibly due to pre-zygotic barriers, such as genomic incompatibility), as noted for the crossings between Panstrongylus and Triatoma, Panstrongylus and Nesotriatoma, Rhodnius Stål, 1859 and Psammolestes Bergroth, 1911 (KCCA, personal communication) and Rhodnius and Triatoma [26]. The reproductive compatibility observed between the $T$. phyllosoma subcomplex species considered in the Meccus genus with species of the Triatoma genus (Table 1) shows that there is "intergeneric" genomic compatibility, which corroborates the regrouping of species in the same genus carried out by Justi et al. [8].

The genus Triatoma is a paraphyletic group comprising 82 species $[3,5,8]$. There are species of Triatoma related phylogenetically to the genera Panstrongylus, Paratriatoma, Linshcosteus and Hermanlentia [8], which justifies the paraphyly of the genus. The inclusion of the species of the genus Meccus in Triatoma rescues a discussion about the application of the morphological characteristics used for a long time as diagnoses for the genera of the subfamily Triatominae (as recently highlighted by Monteiro et al. [27]).

Taxonomy is a fundamental science for the entomoepidemiology of Chagas disease, because correctly classifying triatomines can assist in the activity of vector control programs [28]. Even though since 2014 the generic status of the species grouped in Meccus has been changed to Triatoma, several authors continued publishing articles using the Meccus nomenclature as valid [20, 29-46] and, quite mistakenly, as Triatoma (Meccus) pallidipennis [47-49]-since Meccus after the genus Triatoma (between parentheses) represents a subgenus and, so far, there are no valid subgenera in the subfamily Triatominae.

Table 1 Experimental crosses performed between Triatoma spp. and Meccus spp.

\begin{tabular}{|c|c|c|c|c|c|c|}
\hline \multicolumn{5}{|c|}{ Crossing experiments } & \multirow{2}{*}{$\begin{array}{l}\text { Number of eggs } \\
161\end{array}$} & \multirow{2}{*}{$\begin{array}{l}\text { Egg fertility } \\
98(61 \%)\end{array}$} \\
\hline 우 & T.mopan & $x$ & T. longipennis & 0 & & \\
\hline 우 & T. mazzottii & $x$ & T. mexicana & o & $18^{\mathrm{a}}$ & $12^{\mathrm{a}}(67 \%)$ \\
\hline ㅇ & T. mexicana & $x$ & T. mazzottii & o & $14^{\mathrm{a}}$ & $09^{\mathrm{a}}(64 \%)$ \\
\hline 운 & T. picturatus & $x$ & T. mexicana & o & $25^{\mathrm{a}}$ & $19^{\mathrm{a}}(76 \%)$ \\
\hline ㅇ & T. mexicana & $x$ & T. picturatus & o & $32^{\mathrm{a}}$ & $23^{\mathrm{a}}(72 \%)$ \\
\hline 우남 & T. mexicana & $x$ & T. longipennis & $0^{+}$ & $14^{\mathrm{a}}$ & $9^{a}(64 \%)$ \\
\hline ㅇ & T.phyllosomus & $x$ & T. mexicana & o & $208^{\mathrm{a}}$ & $156^{\mathrm{a}}(75 \%)$ \\
\hline ㅇ & T. mexicana & $x$ & T. phyllosomus & 0 & $392^{\mathrm{a}}$ & $295(75 \%)$ \\
\hline 우 & T. recurva & $x$ & T. longipennis & to & $71.0 \pm 78.3^{b}$ & $6.0 \pm 0^{b}(8,4 \%)$ \\
\hline ㅇ & T. longipennis & $x$ & T. recurva & o & $74.8 \pm 44.6^{b}$ & $6.0 \pm 0^{b}(8 \%)$ \\
\hline 웅 & T. recurva & $x$ & T. picturatus & o & $94.8 \pm 39.6^{\mathrm{b}}$ & $5.7 \pm 6.4^{b}(6 \%)$ \\
\hline ф & T. picturatus & $x$ & T. recurva & o & $136.0 \pm 68.9^{b}$ & $12.3 \pm 15.4^{b}(8.8 \%)$ \\
\hline ㅇ & T. recurva & $x$ & T.pallidipennis & o & $91.2 \pm 77.3^{b}$ & $5.0 \pm 0^{b}(5.5 \%)$ \\
\hline 운 & T.pallidipennis & $x$ & T. recurva & 0 & $54.0 \pm 59.9^{b}$ & $14.5 \pm 13.4^{b}(26.8 \%)$ \\
\hline 우 & T. recurva & $x$ & T. mazzottii & t & $92.7 \pm 56.5^{b}$ & $3.0 \pm 1.3^{b}(3.2 \%)$ \\
\hline ㅇ & T. mazzottii & $x$ & T. recurva & 0 & $119.8 \pm 38.3^{b}$ & $5.3 \pm 0.6^{b}(4.4 \%)$ \\
\hline ㅇ & T. recurva & $x$ & T. phyllosomus & o & $127.8 \pm 88.1^{b}$ & $26.0 \pm 26.7^{b}(20 \%)$ \\
\hline
\end{tabular}

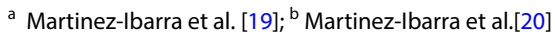




\section{Conclusion}

Thus, through reproductive compatibility, we confirm the generic reorganization of Meccus in Triatoma proposed by Justi et al. [8]. In addition, we highlight the importance of the correct classification of the species of the T. phyllosoma subcomplex into this genus to avoid future misunderstandings by the scientific community and vector control programs.

\section{Acknowledgements}

We appreciate the à Pesquisa do Estado de São Paulo (FAPESP, Brazil), Coordenação de Aperfeiçoamento de Pessoal de Nível Superior (CAPES, Brazil) - Finance Code 001, and Conselho Nacional de Desenvolvimento Científico e Tecnológico (CNPq, Brazil) for financial support.

\section{Authors' contributions}

NRC: conceptualization, methodology, investigation, writing —original draft preparation and writing - review \& editing. JO: conceptualization, methodology, investigation, data curation, and writing —review \& editing. AR: methodology, investigation, and data curation. FFM: methodology, investigation, and data curation. YVR: methodology, investigation, and data curation. ABBO: methodology, investigation, and data curation. RDV: methodology, investigation, and data curation. DCC: methodology, investigation, and data curation. CG: conceptualization, writing - review \& editing, and funding acquisition. MTVAO: conceptualization, funding acquisition, and writing-review \& editing. JAR: conceptualization, resources, and writing — review \& editing. KCCA: conceptualization, methodology, investigation, writing —original draft preparation, writing — review \& editing, supervision, project administration, and funding acquisition. All authors read and approved the final manuscript.

\section{Funding}

The study was supported by Fundação de Amparo à Pesquisa do Estado de São Paulo (FAPESP, Brazil), Coordenação de Aperfeiçoamento de Pessoal de Nível Superior (CAPES, Brazil) - Finance Code 001, and Conselho Nacional de Desenvolvimento Científico e Tecnológico (CNPq, Brazil). JAR: CNPq, PQ-2, process 307 398/2018-8.

\section{Availability of data and materials}

The data supporting the conclusions of this article are included within the article.

\section{Declarations}

Ethics approval and consent to participate

Not applicable.

\section{Consent for publication}

Not applicable.

\section{Competing interests}

The authors declare that they have no competing interests.

\section{Author details}

"Universidade Estadual Paulista "Júlio de Mesquita Filho" (UNESP), Instituto de Biociências, Rua Dr. Antônio Celso Wagner Zanin, 250, Distrito de Rubião Júnior, Botucatu, SP 18618-689, Brazil. Laboratório de Entomologia em Saúde Pública, Departamento de Epidemiologia, Faculdade de Saúde Pública, Universidade de São Paulo, Av. Dr. Arnaldo 715, São Paulo, SP, Brazil. ' ${ }^{3}$ Laboratório de Parasitologia, Universidade Estadual Paulista "Júlio de Mesquita Filho" (UNESP), Faculdade de Ciências Farmacêuticas, Rodovia Araraquara-Jaú km 1, Araraquara, SP 14801-902, Brazil. Laboratório de Biologia Celular, Universidade Estadual Paulista "Júlio de Mesquita Filho" (UNESP), Instituto de Biociências, Letras e Ciências Exatas, Rua Cristóvão Colombo 2265, São José Do Rio Preto, SP 15054-000, Brazil. ${ }^{5}$ Laboratório Nacional e Internacional de Referência em Taxonomia de Triatomíneos, Instituto Oswaldo Cruz (FIOCRUZ), Av. Brasil 4365, Pavilhão Rocha Lima, sala 505, Rio de Janeiro, RJ 21040-360, Brazil.
Received: 22 April 2021 Accepted: 11 June 2021

Published online: 26 June 2021

\section{References}

1. World Health Organization. Chagas disease (American trypanosomiasis). http://www.who.int/news-room/fact-sheets/detail/chagas-disease(american-trypanosomiasis). Accessed 12 Mar 2021.

2. Galvão C. Vetores da doença de Chagas no Brasil. 1ª ed. Curitiba: Sociedade Brasileira de Zoologia; 2014.

3. Justi SA, Galvão C. The evolutionary origin of diversity in Chagas disease vectors. Trends Parasitol. 2017:33:42-52.

4. Galvão C. Taxonomia dos Vetores da Doença de Chagas da Forma à Molécula, quase três séculos de história. In: Oliveira J, Alevi KCC, Camargo LMA, Meneguetti DUO, editores. Atualidades em Medicina Tropical no Brasil: Vetores. São Paulo: Strictu Sensu Editora; 2020. p. 9-37.

5. Alevi KCC, Oliveira J, Garcia ACC, Cristal DC, Delgado LMG, Bittinelli IF, et al. Triatoma rosai sp. nov. (Hemiptera, Triatominae): a new species of argentinian chagas disease vector described based on integrative taxonomy. Insects. 2020;11:830.

6. Zhao Y, Galvão C, Cai W. Rhodnius micki, a new species of Triatominae (Hemiptera, Reduviidae) from Bolivia. ZooKeys. 2021;1012:71-93.

7. Galvão C, Carcavallo R, Rocha DS, Jurberg J. A checklist of the current valid species of the subfamily Triatominae Jeannel, 1919 (Hemiptera, Reduviidae) and their geographical distribution, with nomenclatural and taxonomic notes. Zootaxa. 2003;202:1-36.

8. Justi SA, Russo CAM, dos Mallet JR, Obara MT, Galvão C. Molecular phylogeny of Triatomini (Hemiptera: Reduviidae: Triatominae). Parasit Vect. 2014;7:149.

9. Burmeister H. Handbuch der Entomologie. Berlin: Enslin; 1835.

10. Stål C. Monographie der Gattung Conorhinus und Verwandten. Berl Entomol Zeitsch. 1859;3:99-117.

11. Del Ponte E. Catálogo descriptivo de los géneros Triatoma Lap., Rhodnius Stål, e Eratyrus Stål. Rev. Instituto Bacteriol. Dep. Nac. Hig. 1930; 5: 855-937.

12. Carcavallo RU, Jurberg J, Lent H, Noireau F, Galvão C. Phylogeny of the Triatominae (Hemiptera, Reduviidae). Proposals for taxonomic arrangements Entom Vect. 2000;7:1-99.

13. Hypsa V, Tietz D, Zrzavy J, Rego RO, Galvão C, Jurberg J. Phylogeny and biogeography of Triatominae (Hemiptera, Reduviidae): molecular evidence of a New World origin of the Asiatic clade. Mol Phylog Evol. 2012;23:447-57.

14. Dorn PL, Justi AS, Dale C, Stevens L, Galvão C, Cordon RL, Monroy C. Description of Triatoma mopan sp. n. (Hemiptera, Reduviidae, Triatominae) from a cave in Belize. Zookeys. 2018;775:69-95.

15. Lima-Cordón RA, Monroy MC, Stevens L, Rodas A, Rodas GA, Dorni PL, Justi AS. Description of Triatoma huehuetenanguensis sp. n., a potential Chagas disease vector (Hemiptera, Reduviidae, Triatominae). Zookeys. 2019;820:51-70.

16. Martínez-Hernandez F, Martínez-lbarra JA, Catalá S, Villalobos G, de la Torre P, Laclette J, Alejandre-Aguilar R, Espinoza B. Natural crossbreeding between sympatric species of the Phyllosoma complex (Insecta: Hemiptera: Reduviidae) indicate the existence of only one species with morphologic and genetic variations. Am J Trop Med Hyg. 2010;82:74-82.

17. Martínez-Ibarra JA, Ventura-Rodríguez LV, Meillón-Isáis K, Barajas-Martínez HM, Alejandre-Aguilar P, Lupercio-Coronel R, Rocha-Chávez G, NoguedaTorres B. Biological and genetic aspects of crosses between species of the Phyllosoma complex (Hemiptera: Reduviidae Triatominae). Mem Inst Oswaldo Cruz. 2008;103:236-43.

18. Martínez-Ibarra JA, Grant-Guillén Y, Ventura-Rodríguez LV, Osorio-Pelayo PD, Macías-Amezcua MD, Meillón-Isáis K, Alejandre-Aguilar R, RodríguezBataz E, Nogueda-Torres B. Biological and genetic aspects of crosses between species of the genus Meccus (Hemiptera: Reduviidae Triatominae). Mem Inst Oswaldo Cruz. 2011;106:293-300.

19. Martínez-Ibarra JA, Grant-Guillén Y, Delgadillo-Aceves IN, Zumaya-Estrada FA, Rocha-Chávez G, Salazarschettino PM, Alejandre-Aguilar R, Villalobos G, Nogueda-Torres B. Biological and genetic aspects of crosses between phylogenetically close species of Mexican Triatomines (Hemiptera: Reduviidae). J Med Entomol. 2011:48:705-7. 
20. Martínez-Ibarra JA, Nogueda-Torres B, Licón-Trillo Á, Alejandre-Aguilar R, Salazar-Schettino PM, Vences-Blanco MO. Biological aspects of crosses between Triatoma recurva (Stål), 1868 (Hemiptera: Reduviidae: Triatominae) and other members of the Phyllosoma complex. J Vec Ecol. 2015;40:117-22.

21. Mendonça VJ, Alevi KCC, Pinotti H, Gurgel-Gonçalves R, Pita S, Guerra AL, Panzera F, Araújo RF, Azeredo-Oliveira MTV, Rosa JA. Revalidation of Triatoma bahiensis Sherlock \& Serafim, 1967 (Hemiptera: Reduviidae) and phylogeny of the T. brasiliensis species complex. Zootaxa. 2016:4107:239-54.

22. Nascimento JD, Ravazi A, Alevi KCC, Pardo-Diaz C, Salgado-Roa FC, da Rosa JA, de Azeredo Oliveira MTV, de Oliveira J, Hernández C, Salazar C, Ramírez JD. Taxonomical over splitting in the Rhodnius prolixus (Insecta: Hemiptera: Reduviidae) clade: are $R$. taquarussuensis (da Rosa et al., 2017) and $R$. neglectus (Lent, 1954) the same species? PLoS ONE. 2019;14:e0211285.

23. Neves SJM, Sousa PS, Oliveira J, Ravazi A, Madeira FF, Reis YV, et al. Prezygotic isolation confirms the exclusion of Triatoma melanocephala, $T$. vitticeps and T. tibiamaculata of the T. brasiliensis subcomplex (Hemiptera, Triatominae). Infect Genet Evol. 2020;79:104149.

24. Correia N, Almeida CE, Lima-Neiva V, Gumiel M, Lima MM, Medeiros LMO, Mendonça VJ, Rosa JA, Costa J. Crossing experiments confirm Triatoma sherlocki as a member of the Triatoma brasiliensis species complex. Acta Trop. 2013;128:162-7.

25. Mendonça VJ, Alevi KCC, Medeiros LM, Nascimento JD, Azeredo-Oliveira MTV, Rosa JA. Cytogenetic and morphologic approaches of hybrids from experimental crosses between Triatoma lenti Sherlock \& Serafim, 1967 and T sherlocki Papa et al. 2002 (Hemiptera: Reduviidae). Infect Genet Evol. 2014;26:123-31.

26. Perlowagora-Szumlewics A, Correia MV. Induction of male sterility manipulation of genetic mechanisms present in vector species of Chagas disease (remarks on integrating sterile-male release with insecticidal control measures against vectors of (hagas disease). Rev Inst Med Trop São Paulo. 1972;14:360-71.

27. Monteiro FA, Weirauch C, Felix F, Lazoski C, Abad-Franch F. Evolution, Systematics, and Biogeography of the Triatominae Vectors of Chagas Disease. Adv Parasitol. 2018;99:265-344.

28. Dujardin JP, Costa J, Bustamante D, Jaramillo N, Catala S. Deciphering morphology in Triatominae: the evolutionary signals. Acta Trop. 2009;110:101-11.

29. Martínez-Ibarra JA, Nogueda-Torres B, Vargas-Llamas V, García-Benavides G, Bustos-Saldaña R, Villagrán ME, de Diego-Cabrera JA, Tapia-González JM. Biological characteristics of geographically isolated populations of Meccus mazzottii (Hemiptera: Reduviidae) in southern Mexico. J Ins Sc. 2014;14:1-5.

30. Martínez-Ibarra JA, Nogueda-Torres B, la Cruz MÁ, Villagrán ME, DiegoCabrera JA, Bustos-Saldaña R. Biological parameters of interbreeding subspecies of Meccus phyllosomus (Hemiptera: Reduviidae: Triatominae) in western Mexico. Bull Entomol Res. 2015;105:763-70.

31. Martínez-Ibarra JA, Nogueda-Torres B, del Toro-González AK, VenturaAnacleto LÁ, Montañez-Valdez OD. Geographic variation on biological parameters of Meccus picturatus (Usinger), 1939 (Hemiptera: Reduviidae: Triatominae) under laboratory conditions. J Vec Ecol. 2015:40:66-70.

32. Martínez-Ibarra JA, Nogueda-Torres B, Salazar-Schettino PM, CabreraBravo M, Vences-Blanco MO, Rocha-Chavez G. Transmission Capacity of Trypanosoma cruzi (Trypanosomatida: Trypanosomatidae) by Three Subspecies of Meccus phyllosomus (Heteroptera: Reduviidae) and Their Hybrids. Med Veter Entom. 2016;53:928-34.

33. Martínez-Ibarra JA, Nogueda-Torres B, García-Lin JC, Arroyo-Reys D, Salazar-Montaño LF, Hernández-Navarro JA, Díaz-Snches CG, Toro-Arreola ES, Rocha-Chávez G. Importance of Hybrids of Meccus phyllosomus mazzottii, and M. p. pallidipennis, and M p phyllosomus to the Transmission of Trypanosoma cruzi in Mexico. Jap J Infect Dis. 2016;69:202-6.

34. Martínez-Ibarra JA, Nogueda-Torres B, Salazar-Montaño LF, García-Lino JC, Arroyo-Reyes D, Hernández-Navarro JÁ. Comparison of biological fitness in crosses between subspecies of Meccus phyllosomus (Hemiptera: Reduviidae: Triatominae) in southern Mexico. Ins Sc. 2017;24:114-21.
35. Valenzuela-Campos R, González-Rangel N, Nogueda-Torres B, GoicocheaDel Rosal G, Martínez-Ibarra JA. Biological characteristics of Meccus phyllosomus pallidipennis (Hemiptera: Reduviidae: Triatominae) fed on two different hosts. Rev Soc Bras Med Trop. 2019;52:e20190020.

36. Rivas N, Sánchez-Cordero V, Camacho AD, Alejandre-Aguilar R. External female genitalia of six species of the genus Meccus (Hemiptera: Reduviidae: Triatominae). J Vector Ecol. 2017:42:271-8.

37. Díaz L, Covarrubias K, Licón A, Astorga M, Moreno Y, Martínez JA. Parámetros biológicos de Meccus phyllosomus phyllosomus (Burmeister) 1835, de Triatoma recurva (Stål) 1868 (Hemiptera, Reduviidae) y de sus híbridos de laboratório. Biomedica. 2017;37:77-82.

38. Favila-Ruiz G, Jiménez-Cortés JG, Córdoba-Aguilar A, Salazar-Schettino PM, Gutiérrez-Cabrera AE, Pérez-Torres A, De Fuentes-Vicente JA, VencesBlanco MO, Bucio-Torres MI, Flores-Villegas AL, Cabrera-Bravo M. Effects of Trypanosoma cruzi on the phenoloxidase and prophenoloxidase activity in the vector Meccus pallidipennis (Hemiptera:Reduviidae). Parasit Vectors. 2018;11:434.

39. Flores-Villegas AL, Cabrera-Bravo M, Toriello C, Bucio-Torres MI, SalazarSchettino PM, Córdoba-Aguilar A. Survival and immune response of the Chagas vector Meccus pallidipennis (Hemiptera: Reduviidae) against two entomopathogenic fungi, Metarhizium anisopliae and Isaria fumosorosea. Parasit Vectors. 2016;9:176.

40. Flores-Villegas AL, Cabrera-Bravo M, Pérez-Torres A, Córdoba-Aguilar A, Salazar-Schettino PM, Hernández-Velázquez VM, Toriello C. Effects on Meccus pallidipennis (Hemiptera: Reduviidae) eggs exposed to entomopathogenic fungi: exploring alternatives to control Chagas disease. J Med Entomol. 2018:56:284-90.

41. Flores-Villegas AL, Cabrera-Bravo M, Fuentes-Vicente JA, Jiménez-Cortés JG, Salazar-Schettino M, Bucio-Torres MI, Córdoba-Aguilar A. Coinfection by Trypanosoma cruzi and a fungal pathogen increases survival of Chagasic bugs: advice against a fungal control strategy. B Entomol Res. 2020;110:363-9.

42. López-Vias FI, Vázques-Chagoyán JC, Acosta-Dibarrat JP, Medina-Torres I, Diaz-Albiter M, Fernández-Rosas P, Oca-Jiménez RM. Molecular Characterization of Trypanosoma cruzi in Infected Meccus pallidipennis in the Southern Region of the State of Mexico. Mexico Vector-Borne and Zoonotic Dis. 2018;18:683-9.

43. Murillo-Alonso KT, Hernández-Velázquez VM, Salazar-Schettino PM, Cabrera-Bravo M, Toriello C. Effects of Metarhizium anisopliae on Meccus pallidipennis (Hemiptera: Reduviidae) over different types of wall surfaces. Biocontrol Sci Technol. 2019;29:466-77.

44. Madeira FF, Lima ACC, Rosa JA, Azeredo-Oliveira MTV, Alevi KCC. Nucleolar persistence phenomenon during spermatogenesis in genus Meccus (Hemiptera, Triatominae). Genet Mol Res. 2016: gmr.15017427.

45. Madeira FF, Borsatto KC, Lima ACC, Ravazi A, Oliveira J, Rosa JA, AzeredoOliveira MTV, Alevi KCC. Nucleolar persistence: peculiar characteristic of spermatogenesis of the vectors of chagas disease (Hemiptera, Triatominae). Am J Trop Med Hyg. 2016;95:1118-20.

46. Alevi KCC, Oliveira J, Rosa JA, Azeredo-Oliveira MTV. Coloration of the testicular peritoneal sheath as a synapomorphy of triatomines (Hemiptera, Reduviidae). Biota Neotrop. 2014;14:1-3.

47. Diaz-Garrido P, Sepulveda-Robles O, Martinez-Martinez I, Espinoza B. Variability of defensin genes from a Mexican endemic Triatominae: Triatoma (Meccus) pallidipennis (Hemiptera: Reduviidae). Biosci Rep. 2018;38:1-11.

48. Gutiérrez-Cabrera AE, Alejandre-Aguilar R, Hernández-Martínez S, Espinoza B. Development and glycoprotein composition of the perimicrovillar membrane in Triatoma (Meccus) pallidipennis (Hemiptera: Reduviidae), Arthropod Struct Dev. 2014;43:571-8.

49. Gutiérrez-Cabrera AE, Zandberg WF, Zenteno E, Rodríguez MH, Espinoza B, Lowenberger C. Glycosylation on proteins of the intestine and perimicrovillar membrane of Triatoma (Meccus) pallidipennis, under different feeding conditions. Insect Sci. 2019;26:796-808.

\section{Publisher's Note}

Springer Nature remains neutral with regard to jurisdictional claims in published maps and institutional affiliations. 